\title{
Microencapsulation and co-encapsulation of bioactive compounds for application in food: challenges and perspectives
}

\section{Greice Carine Raddatz ${ }^{1}\left[\right.$ Cristiano Ragagnin de Menezes $^{1 *}$ (C)}

${ }^{1}$ Departamento de Ciência e Tecnologia de Alimentos, Universidade Federal de Santa Maria (UFSM), 97105-900, Santa Maria, RS, Brasil. E-mail: cristiano.ufsm@gmail.com. "Corresponding author.

ABSTRACT: The availability of different food products containing bioactive compounds promotes their inclusion in the daily diet of consumers. However, the effective and safe delivery of such products requires certain precautions to ensure their preservation, stability, and bioavailability when consumed. Microencapsulation is a great alternative, which is a method capable of protecting different bioactive compounds, including probiotic cells, prebiotic compounds, and some antioxidant substances such as phenolic compounds, anthocyanins, flavonoids, and vitamins. Therefore, this study aimed to perform a literature review and present different alternatives to make bioactive compounds viable through microencapsulation, increase their stability and viability when applied in different food matrices, and address the existing challenges regarding their effectiveness.

Key words: microcapsules, probiotics, prebiotics, antioxidants, co-encapsulation.

Microencapsulação e co-encapsulação de compostos bioativos para aplicação em alimentos: desafios e perspectivas

RESUMO: A oferta de diferentes produtos alimentícios que contenham compostos bioativos facilita a sua inserção na dieta como parte do dia a dia do consumidor. No entanto, para que estes compostos sejam entregues de forma segura e eficaz, o uso de certos meios se torna necessário para garantir sua preservação, estabilidade e biodisponibilidade quando consumidos. Com esta finalidade, apresenta-se como uma grande alterativa a microencapsulação, que é um método capaz de fornecer proteção a diferentes compostos bioativos, que incluem células probióticas, compostos prebióticos, e algumas substâncias antioxidantes como compostos fenólicos, antocianinas, flavonoides, vitaminas, dentre outros e garantir uma melhor efetividade na sua entrega. O objetivo deste trabalho foi realizar uma revisão apresentando formas de viabilizar os compostos bioativos através da microencapsulação, para aumentar sua estabilidade e viabilidade diante da aplicação em diferentes matrizes alimentícias, além de abordar os desafios existentes para a sua efetividade.

Palavras-chave: microcápsulas, probióticos, prebióticos, antioxidantes, co-encapsulação.

\section{INTRODUCTION}

Bioactive compounds are important substances due to their role in disease prevention and functional profile (BAO et al., 2019). In this context, nutritional and functional foods have become a promising niche in the current market due to new trends in consumer eating habits. Within the group of functional compounds, which is quite broad, probiotic bacteria, prebiotic compounds, and antioxidant compounds deserve to be highlighted.

Probiotics are live microorganisms that provide positive effects to the host when ingested in adequate amounts (HILL et al., 2014).
Prebiotics, on the other hand, are non-digestible food components that selectively stimulate probiotic growth (ROBERFROID et al., 2010). Symbiotics are a combination of probiotics and prebiotics that confer beneficial effects to the immune system against pathogenic microorganisms, in addition to their role against some types of cancer and anti-allergic action (OLIVEIRA \& GONZÁLEZ-MOLERO, 2016; CADIEUX, et al., 2008).

Likewise, antioxidants are a powerful tool in disease prevention and combat oxidative stress in the cells of the body by inhibiting or delaying damage caused by free radicals (OROIAN \& ESCRICHE, 2015). 
Despite such benefits, these compounds are usually unstable in light, humidity, oxygen, and temperature. In addition, they must withstand acidic stomach conditions and enzymes present throughout the gastrointestinal tract (CHEN et al., 2011; WEN et al., 2017).

One possible approach for the food industry to adapt to this scenario and overcome these challenges is through the development and offer of new functional foods, making microencapsulation a promising alternative. Co-encapsulation is another technique, as it incorporates different functional compounds and allows a single food matrix to present a combination of beneficial and synergistic effects, although this is a novel area and requires further studies regarding its use in developing functional foods.

Therefore, the present literature review aimed to address the development of new functional foods containing different bioactive compounds using different encapsulation techniques in order to overcome the challenges of maintaining the shelf life of these compounds and increase their viability and functionality.

\section{Microencapsulation and co-encapsulation}

Microcapsules are excellent means of introducing bioactive compounds into food or beverages to develop new functional foods. There are different techniques to produce microcapsules such as physical methods, including freezedrying, spray drying, solvent evaporation, and precipitation with supercritical fluids. Physicalchemical methods include internal and external ionic gelation, complex coacervation, and liposomes. In addition, microencapsulation can be carried out by chemical methods, such as by molecular inclusion complexation and interfacial polymerization (TYAGI et al., 2011).

Selecting a suitable method to produce microcapsules depends on the desired particle size, the target food, production costs, peculiarities of the material to be encapsulated, wall material, release rate of the active material, etc. (KHADIRAN et al., 2015; ZHU, 2017). The wall or encapsulating material surrounding the nucleus or active material can be comprised of several components, including polysaccharides, lipids, and proteins.

The encapsulation of two or more bioactive compounds into a single matrix is called co-encapsulation (CHEN et al., 2013) (Figure 1). By combining different active compounds, greater viability and bioavailability can be achieved compared to isolated encapsulated elements (ZHANG et al., 2019).

ZAEIM at al. (2019) successfully coencapsulated probiotics with prebiotics. BAO et al. (2020) also used co-encapsulation to combine the beneficial properties of $\alpha$-tocopherol and resveratrol into the same matrix. COMUNIAN et al. (2020) described the co-encapsulation of pequi and buriti oils by emulsification and freeze-drying as a promising method to protect carotenoids and increase oxidative stability. HOLKEM et al. (2020) also described the advantages of co-encapsulation to protect probiotics and a proanthocyanidin-rich cinnamon extract against the gastrointestinal tract.

\section{Symbiotic foods}

The most commonly used and studied probiotics belong to the genera Bifidobacterium and Lactobacillus. Probiotic cells bolster the immune

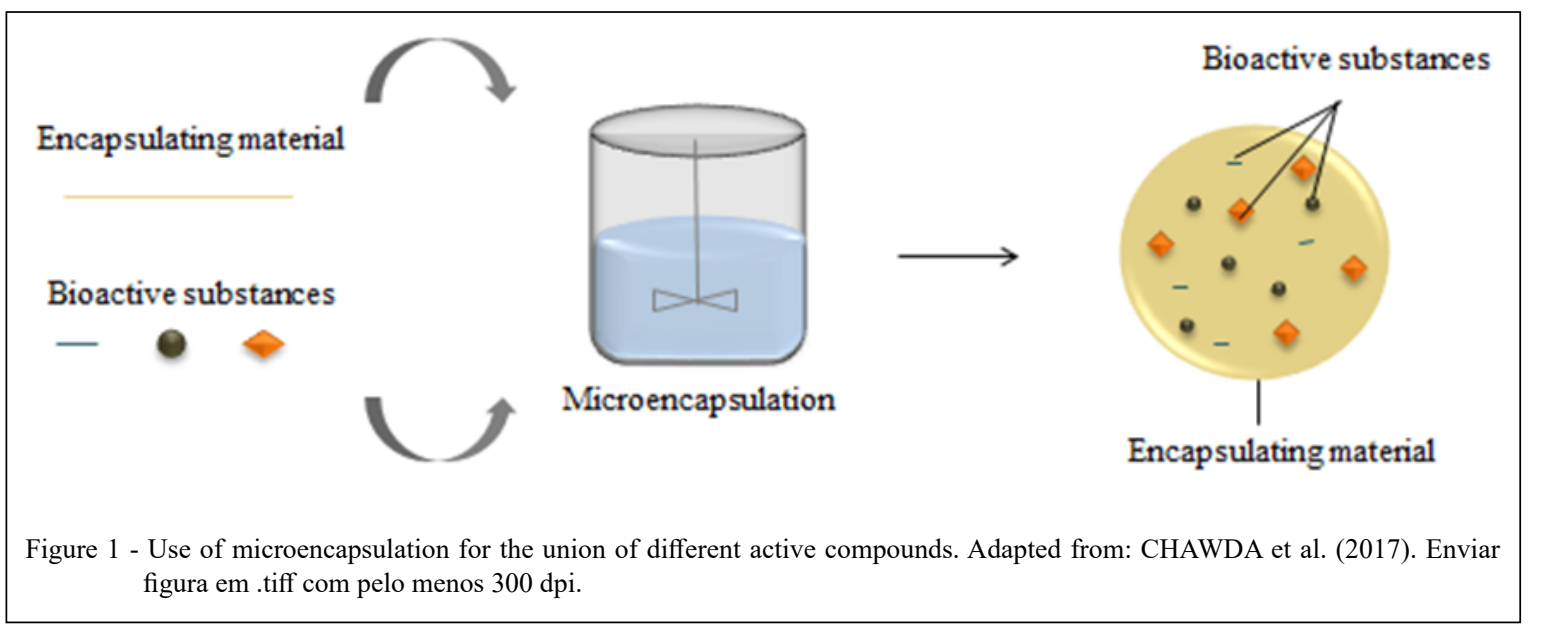

Ciência Rural, v.51, n.3, 2021. 
system (MORO-GARCÍA et al., 2013), fight pathogens, modulate intestinal flora, reduce lactose intolerance, and have anti-cancer and anti-inflammatory effects (VASILJEVIC \& SHAH, 2008; GEORGE KERRY et al., 2018; ALMADA et al., 2015).

Various studies have reported higher microencapsulated probiotic microorganism viability compared to free cells, especially in conditions simulating the gastrointestinal tract (GEBARA et al., 2013; RADDATZ et al 2020). Most commercialized foods that contain probiotic properties are of dairy origin and kept refrigerated (BURGAIN et al., 2011). In this context, new studies have sought to microencapsulate probiotics in different food matrices, such as soy protein bars (CHEN \& MUSTAPHA, 2012), green coconut water (BASU et al., 2018), and acerola nectar (ANTUNES et al., 2013). However, achieving the probiotic effects requires a daily intake of at least $10^{6}$ $\mathrm{CFU} / \mathrm{g}$ or $\mathrm{ml}$ at the time of ingestion (CHAMPAGNE et al., 2011). This is still an obstacle for the development of functional foods containing probiotics in view of their sensitivity to adverse conditions.

Symbiotic microparticles are capable of increasing the survival rates of probiotic microorganisms after exposure to simulated gastrointestinal tract (POLETTO et al., 2019). Among the existing prebiotics, it is possible to highlight inulin, Hi-maize, galacto-oligosaccharides (GOS), fructo-oligosaccharides (FOS), xylooligosaccharides, pectin, lactulose, soy oligosaccharides, and lactitol xylitol (SIRÓ et al., 2008).

In addition to being rich in nutrients, interest in prebiotics increases due to their ability to improve certain organoleptic properties in food (DE MORAIS et al., 2015). The ingestion of prebiotics confers innumerous benefits to human health, such as selectively stimulating probiotic bacteria, modulating mineral absorption, promoting a feeling of satiety, increasing weight loss, reducing the risk of some types of cancer, and improving cholesterol and glucose control (SAAD et al., 2013; POKUSAEVA et al., 2011).

ANEKELLA \& ORSAT (2013) developed a symbiotic raspberry juice to evaluate the possible prebiotic effects of maltodextrin as a carbon source. PAIM et al. (2016) analyzed prebiotic jussara juice (Euterpe edulis M.) containing Bifidobacterium spp. Lactis microencapsulated with different prebiotics (inulin and oligofructose) and maltodextrin and described high probiotic survival rates after encapsulation. GANDOMI et al. (2016) developed apple juice using probiotic capsules and evaluated the effect of adding prebiotic inulin. The authors reported that probiotic survival during storage and passage through the gastrointestinal tract improved with good sensory acceptance of the product.

Furthermore, KRASAEKOOPT \& WATCHARAPOKA (2014) observed improved probiotic protection when microencapsulating Lactobacillus acidophilus 5 and Lactobacillus casei 01 in alginate and chitosan with galactooligosaccharides and inulin prebiotics for use in commercial yogurt and orange juice.

\section{Foods containing antioxidants}

Antioxidants are powerful tools against degenerative diseases and some types of cancer. These compounds arouse the interest of the food industry as food preservatives since they decrease product deterioration caused by oxidation, in addition to reducing the nutritional loss of the food and improving the conservation of their organoleptic characteristics, pigment, color, and odor (MARTYSIAKZUROVSKA \& WENTA, 2012; PISOSCHI \& POP, 2015; EROGLU OZKAN et al., 2018).

Some commonly consumed foods, such as fruits, cereals, legumes, and vegetables have antioxidant compounds; however, their consumption alone may not be enough for the necessary intake of antioxidants(YASHIN etal., 2013). In addition, factors such as the presence of light, oxygen, and temperature may cause food degradation; consequently, hindering any antioxidant and functional effects. Thus, the use of microencapsulation is an effective alternative to protect antioxidant compounds and their application in new functional foods.

Food antioxidants are categorized into water-soluble compounds, the more notable being phenolic, anthocyanin, flavonoid, citrate, betalain, norbixin, and liposoluble compounds, which include vitamins, carotenes, tocopherols, and terpenoids (CAROCHO et al., 2017). In addition, natural extracts from plants have greater antioxidant capacity compared to synthetic antioxidants (BISWAS et al., 2017).

In the bakery industry, different matrices have already been studied for the application of microcapsules containing antioxidant compounds, for example, a biscuit model with cocoa hulls phenolic extracts (PAPILLO et al., 2018) and pseudocerealenriched einkorn water biscuits to evaluate the addition of red beetrood pomace extracts (HIDALGO et al., 2018).

In the meat products industry, BALDIN et al. (2018) developed mortadella sausages with a microencapsulated jaboticaba extract. SPINELLI et al. (2016) microencapsulated polyphenols and 
flavonoids extracted from used grains from a brewery and applied them to fish hamburgers. The authors were able to mask the unpleasant and bitter taste of the extract and achieve greater antioxidant capacity and bioactive content compared to the control sample. ZOKTI et al. (2016) also used microencapsulation to add a green tea extract to mango juice and reported lower degradation rates and greater stability and antioxidant capacity compared to the nonencapsulated material.

New functional foods with the combination of bioactive compounds

Foods or beverages that have a combination of different bioactive sources facilitate the introduction of these compounds as part of the daily diet of consumers. In addition, the constant competitiveness between the food industries leverages interest in the development of innovative products (DE PELSMAEKER et al., 2015).

REID (2002) reported that the combination of probiotic cells with some types of anthocyanins confer synergistic effects on the immunity of the host. Likewise, catechins, which have potential antioxidant activity, improve probiotic survival in foods during their shelf life (SHAH et al., 2010). Furthermore, SU et al. (2008) demonstrated synergistic effects to combat human pathogens by associating green tea extract and probiotic cells. GAUDREAU et al. (2016) successfully co-encapsulated Lactobacillus helveticus and green tea extracts by internal emulsification/ gelation; although, the behavior of the microcapsules in a food matrix was not evaluated.

RIBEIRO et al. (2015) obtained synergistic effects by joining antioxidant extracts of Suillus luteus (L.: Fries) (Sl) and Cooprinopsis atramentaria (Bull.) (Ca) mushrooms. The authors also co-encapsulated the extracts by spray drying, added them to cottage cheese, and noted greater extract preservation by encapsulation.

Similarly, VAZIRI et al. (2018) mixed Lactobacillus plantarum with DHA-rich oil by comicroencapsulation and observed high resistance to simulated gastrointestinal tract conditions. However, the authors did not apply the microparticles to a food matrix.

SHINDE et al. (2014) used coencapsulation to mix Lactobacillus acidophilus and an aqueous or ethanolic extract of polyphenol from apple skin and apply it to a model milk drink. The co-encapsulated probiotic with aqueous or ethanolic extract showed the lowest loss of viability compared to the free probiotic and encapsulated probiotic without the extracts after $50 \mathrm{~d}$ at $4{ }^{\circ} \mathrm{C}$. The co-encapsulation of probiotic bacteria has also been studied in combination with omega-3 (ERATTE et al., 2017). A probiotic petit suisse cheese added with non-encapsulated jabuticaba skin or bark extract also showed high anti-toxicity activity and probiotic survival; however, the behavior and viability of these compounds in the gastrointestinal tract were not evaluated (PEREIRA et al., 2016a; PEREIRA et al., 2016b).

CHAIKHAM (2015) increased the survival of probiotic cells by co-encapsulating with a cashew extract, green tea extract, and adding the product to fruit juices (blackberry, maoberry, longan, and melon) and stirred yogurt.

Challenges and effectiveness of applying bioactive compounds in the development of new functional foods

Microencapsulating active compounds is an effective means of meeting the constant changes of the consumer market, allowing the food industry to create products with functional and nutritional appeal. However, the industry still faces several challenges in order for these compounds to remain viable throughout the storage period and when ingested.

Determining the correct wall material is essential for successful microencapsulation, as it will influence the size, shape, viscosity, and even the stability of the microcapsules during storage. Moreover, the wall material must protect the nucleus from unfavorable conditions and mask unwanted sensory aspects that certain bioactive compounds tend to present (WEINBRECK et al., 2010).

Sensory evaluations are an important factor when analyzing the acceptance of a new food product, as microcapsule sizes can range from 0.2 to $5000 \mu \mathrm{m}$ (SILVA et al., 2014). To prevent the microcapsules from being sensorially perceived, which results in poor acceptance by the consumer, choosing products with adequate physical parameters (viscosity, consistency, and texture) and capable of masking the microcapsules may be an alternative.

When inserting microcapsules containing bioactive substances into food, aspects of the food matrix itself may be limiting factors for the prolonged stability of the active compound, in addition to the conditions in which they are stored in, including the presence of light and/or high temperatures. Further research must evaluate the effectiveness of foods containing microcapsules throughout their shelf life in order to comply with their claims and provide the declared functional effects when consumed. Finally, the functional food must be resistant to the intestinal tract in order to provide health benefits, 
with the microcapsules being released only at their place of action (JYOTHI et al., 2010). Simulating the passage through the gastrointestinal tract and in vivo simulations may be alternatives for this, as it is possible to verify if the microcapsules keep the active compound viable and bioavailable after contact with bile salts and low $\mathrm{pH}$. Thus, the authors believe that only by considering such aspects can the challenges of incorporating one or more functional compounds into food be overcome.

\section{CONCLUSION}

Microencapsulation and co-encapsulation of bioactive substances are promising methodologies, providing positive results and meeting the technological challenge of maintaining compound stability and viability. Moreover, these alternatives enable the development of new food products, increase the range options for the consuming public, and promote greater nutritional values and therapeutic benefits with lower processing costs for product development. Nevertheless, further studies are necessary, especially regarding in vivo application. In addition, microencapsulation and co-encapsulation behavior and stability in different food matrices and their effects should be evaluated and proven through trials and research while aiming to improve the well-being of the population and fight diseases in a practical and healthy way.

\section{ACKNOWLEDGEMENTS}

Coordenação de Aperfeiçoamento de Pessoal de Nível Superior (CAPES), Brasil - Finance code 001.”

\section{DECLARATION OF CONFLICT OF INTERESTS}

The authors declare no conflict of interest. The founding sponsors had no role in the design of the study; in the collection, analyses, or interpretation of data; in the writing of the manuscript, and in the decision to publish the results.

\section{AUTHORS' CONTRIBUTIONS}

The authors contributed equally to the manuscript.

\section{REFERENCES}

ALMADA, C. N. et al. Characterization of the intestinal microbiota and its interaction with probiotics and health impacts. Applied Microbiology and Biotechnology, v.99, p.41754199, 2015. Available from: <https://www.ncbi.nlm.nih.gov/ pubmed/25895093>. Accessed: Oct. 13, 2018. doi: 10.1007/ s00253-015-6582-5.
ANEKELLA, K.; ORSAT, V. Optimization of microencapsulation of probiotics in raspberry juice by spray drying. LWT - Food Science and Technology, v.50, n.1, p.17-24, 2013. Available from: $<$ https:// www.sciencedirect.com/science/article/pii/S0023643812003313>. Accessed: Nov. 11, 2018. doi: 10.1016/j.lwt.2012.08.003.

ANTUNES, A. E. C. et al. Acerola nectar with added microencapsulated probiotic. LWT - Food Science and Technology, v.54, n.1, p.125-131, 2013. Available from: $<$ https:// www.sciencedirect.com/science/article/pii/S0023643813001473>. Accessed: Oct. 23, 2018. doi: 10.1016/j.lwt.2013.04.018.

BAO, C. et al. The delivery of sensitive food bioactive ingredients: Absorption mechanisms, influencing factors, encapsulation techniques and evaluation models. Food Research International, v.120, p.130-140, 2019. Avaliable from: <https://www. sciencedirect.com/science/article/abs/pii/S0963996919301115>. Accessed: Jan. 19, 2019. doi: 10.1016/j.foodres.2019.02.024.

BAO, H. et al. $\alpha$-Tocopherol and resveratrol in emulsion-filled whey protein gels: Co-encapsulation and in vitro digestion. International Dairy Journal, v.104, 2020. Available from: $<$ https://www.sciencedirect.com/science/article/abs/pii/ S0958694620300194>. Accessed: Feb. 14, 2020. doi: 10.1016/j. idairyj.2020.104649.

BALDIN, J. C. et al. Effect of microencapsulated Jabuticaba ( Myrciaria cauliflora) extract on quality and storage stability of mortadella sausage. Food Research International, v.108, p.551557, 2018. Available from: <https://www.sciencedirect.com/ science/article/abs/pii/S0963996918302667>. Accessed: Dec. 01, 2018. doi: 10.1016/j.foodres.2018.03.076.

BASU, S. et al. Controlled release of microencapsulated probiotics in food matrix. Journal of Food Engineering, v.238, p.61-69, 2018. Available from: <https://www.sciencedirect.com/science/ article/pii/S0260877418302553 > . Accessed: Oct. 22, 2018. doi: 10.1016/j.jfoodeng.2018.06.005.

BISWAS, A. K. et al. (2017). Natural antioxidants in poultry products. In R. Banerjee, A. K. Verma, \& M. W. Siddiqui (Eds.), Natural antioxidants: applications in foods of animal origin (pp. 165-201). Canada: 606 Apple Academic Press, Inc.

BURGAIN, J. et al. Encapsulation of probiotic living cells: From laboratory scale to industrial applications. Journal of Food Engineering, v.104, n.4, p.467-483, 2011. Available from: $\quad<$ https://www.sciencedirect.com/science/article/pii/ S026087741000631X>. Accessed: Oct. 19, 2018. doi: 10.1016/j. jfoodeng.2010.12.031.

CADIEUX, P. et al. Evaluation of reuterin production in urogenital probiotic Lactobacillus reuteri RC-14. Journal of Applied and Environmental Microbiology, v.74, p.4645-4649, 2008. Available from: <https://aem.asm.org/content/74/15/4645>. Accessed: Jun. 21, 2018. doi: 10.1128/AEM.00139-08.

CAROCHO, M. et al. Antioxidants: Reviewing the chemistry, food applications, legislation and role as preservatives. Trends in Food Science \& Technology, v.71, p.107-120, 2017. Available from: <https://www.sciencedirect.com/science/ article/pii/S0924224417306568>. Accessed: Nov. 26, 2018. doi: 10.1016/j.tifs.2017.11.008.

CHAIKHAM, P. Stability of probiotics encapsulated with Thai herbal extracts in fruit juices and yoghurt during refrigerated storage.

Ciência Rural, v.51, n.3, 2021. 
Food Bioscience, v.12, n.1, p.61-66, 2015. Available from: <https:// www.sciencedirect.com/science/article/pii/S2212429215300110>. Accessed: Oct. 27, 2019. doi: 10.1016/j.fbio.2015.07.006.

CHAMPAGNE, C. P. et al. Recommendations for the viability assessment of probiotics as concentrated cultures and in food matrices. International Journal of Food Microbiology, v.149, n.3, p.185-193, 2011. Available from: <https://www.sciencedirect. com/science/article/pii/S0168160511003795>. Accessed: Nov. 02, 2018. doi: 10.1016/j.ijfoodmicro.2011.07.005.

CHAWDA, P. J. et al. Co-encapsulation of bioactives for food applications. Food Quality and Safety, v.1, n.4, p.302309, 2017. Available from: <https://academic.oup.com/fqs/ article/1/4/302/4735174>. Accessed: Oct. 03, 2019. doi: 10.1093/ fqsafe/fyx 028 .

CHEN, M. C. et al. A review of the prospects for polymeric nanoparticle platforms in oral insulin delivery. Biomaterials, v.32, n.36, p.9826-9838, 2011. Available from: <https://www. sciencedirect.com/science/article/pii/S0142961211010350>. Accessed: Jun. 22, 2018. doi: 10.1016/j.biomaterials.2011.08.087.

CHEN, M.; MUSTAPHA,A. Survival of freeze-dried microcapsules of a-galactosidase producing probiotics in a soy bar matrix. Food Microbiology, v.30, n.1, p.68-73, 2012. Available from: <https:// www.sciencedirect.com/science/article/pii/S0740002011002681>. Accessed: Oct. 22, 2018. doi: 10.1016/j.fm.2011.10.017.

CHEN, Q. et al. Co-encapsulation of fish oil with phytosterol esters and limonene by milk proteins. Journal of Food Engineering, v.117, n.4, p.505-512, 2013. Available from: <https://www. sciencedirect.com/science/article/pii/S0260877413000241>. Accessed: Aug. 11, 2018. doi: 10.1016/j.jfoodeng.2013.01.011.

COMUNIAN, T. A. et al. S. Reducing carotenoid loss during storage by co-encapsulation of pequi and buriti oils in oil-in-water emulsions followed by freeze-drying: Use of heated and unheated whey protein isolates as emulsifiers. Food Research International, v.130, 2020. Available from: <https://www.sciencedirect.com/ science/article/abs/pii/S0963996919307872>. Accessed: Feb. 16, 2020. doi: 10.1016/j.foodres.2019.108901.

DE MORAIS, E. C. et al. Prebiotic and diet/light chocolate dairy dessert: chemical composition, sensory profiling and relationship with consumer expectation. LWT e Food Science and Technology, v.62, n.1, p.424-430, 2015. Available from: <https:// www.sciencedirect.com/science/article/pii/S0023643814007919>. Accessed: Nov. 07, 2018. doi: 10.1016/j.lwt.2014.12.015.

DE PELSMAEKER, S. et al. Consumer-driven product development and improvement combined with sensory analysis: a case-study for European filled chocolates. Food Quality and Preference, v.41, p.20-29, 2015. Available from: <https://www. sciencedirect.com/science/article/pii/S0950329314002092>. Accessed: Oct. 02, 2018. doi: 10.1016/j.foodqual.2014.10.009.

ERATTE, D. et al. In-vitro digestion of probiotic bacteria and omega-3 oil co-microencapsulated in whey protein isolate-gum Arabic complex coacervates, Food Chemistry, v.227, n.15, p.129-136, 2017. Available from: <https://www.sciencedirect. com/science/article/pii/S0308814617300912>. Accessed: Dec. 14, 2018. doi: 10.1016/j.foodchem.2017.01.080.

EROGLU OZKAN, E. et al. Evaluation of chemical composition, antioxidant and anti-acetylcholinesterase activities of Hypericum neurocalycinum and Hypericum malatyanum. South African Journal of Botany, v.114, p.104-110, 2018. Available from: <https:// www.sciencedirect.com/science/article/pii/S0254629917306233>. Accessed: Nov. 18, 2018. doi: 10.1016/j.sajb.2017.10.022.

GANDOMI, H. et al. Effect of chitosan-alginate encapsulation with inulin on survival of Lactobacillus rhamnosus GG during apple juice storage and under simulated gastrointestinal conditions, LWT - Food Science and Technology, v.69, p.365-371, 2016. Available from: <https://www.sciencedirect.com/science/ article/pii/S0023643816300640>. Accessed: Nov. 12, 2018. doi: 10.1016/j.lwt.2016.01.064.

GAUDREAU, $\mathrm{H}$. et al. Co-encapsulation of Lactobacillus helveticus cells and green tea extract: Influence on cell survival in simulated gastrointestinal conditions. Journal of Functional Foods, v.26, p.451-459, 2016. Available from: <https://www. sciencedirect.com/science/article/pii/S1756464616302109>. Accessed: Oct. 13, 2018. doi: 10.1016/j.jff.2016.08.002.

GEBARA, C. et al. Viability of Lactobacillus acidophilus La-05 in pectin-whey protein microparticles during exposure to simulated gastrointestinal conditions. Food Research International, v.51, n.2, p.872-878, 2013. Available from: $<$ https://www.sciencedirect. com/science/article/pii/S0963996913001014>. Accessed: jan. 19, 2020. doi: https://doi.org/10.1016/j.foodres.2013.02.008.

GEORGE KERRY R, et al., Benefaction of probiotics for human health: A review. Journal of Food and Drug Analysis, v.26, n.3, p.927-939, 2018. Available from: <https://www.sciencedirect. com/science/article/pii/S1021949818300309>. Accessed: Oct. 13, 2018. doi: 10.1016/j.jfda.2018.01.002.

HIDALGO, A. et al. Microencapsulates and extracts from red beetroot pomace modify antioxidant capacity, heat damage and colour of pseudocereals-enriched einkorn water biscuits. Food Chemistry, v.268, p.40-48, 2018. Available from: $<$ https://www. sciencedirect.com/science/article/pii/S030881461831032X>. Accessed: Oct. 12, 2018. doi: 10.1016/j.foodchem.2018.06.062.

HILL, C. et al. Expert consensus document: The international scientific association for probiotics and prebiotics consensus statement on the scope and appropriate use of the term probiotic. Nature Reviews Gastroenterology and Hepatology, v.11, n.8, p.506-514, 10 jun. 2014

HOLKEM, A. T. et al. Study of anticancer properties of proanthocyanidin-rich cinnamon extract in combination with Bifidobacterium animalis subsp. lactis BLC1 and resistance of these free and co-encapsulated materials under in vitro simulated gastrointestinal conditions. Food Research International, v.134, 2020. Available from: <https://www.sciencedirect.com/science/ article/abs/pii/S0963996920302994>. Accessed: May, 15, 2020. doi: 10.1016/j.foodres.2020.109274.

JYOTHI, N. V. N. P. et al. Microencapsulation techniques, factors influencing encapsulation efficiency. Journal of Microencapsulation, 2010. Available from: $<$ https://pubmed.ncbi. nlm.nih.gov/20406093/>. Accessed: Apr. 23, 2020.

KHADIRAN, T. et al. Encapsulation techniques for organic phase change materials as thermal energy storage medium: a review. Solar Energy Materials and Solar Cells, v.143, p.78-98, 2015. Available from: <https://www.sciencedirect.com/science/ article/pii/S0927024815003086>. Accessed: Aug. 08, 2018. doi: 10.1016/j.solmat.2015.06.039. 
KRASAEKOOPT, W.; WATCHARAPOKA, S. Effect of addition of inulin and galactooligosaccharide on the survival of microencapsulated probiotics in alginate beads coated with chitosan in simulated digestive system, yogurt and fruit juice. LWT - Food Science and Technology, v.57, p.761-766, 2014. Available from: <https://www.sciencedirect.com/science/ article/pii/S0023643814000541>. Accessed: Nov. 12, 2018. doi: 10.1016/j.1wt.2014.01.037.

MARTYSIAK-ZUROVSKA, D.; WENTA, W. A comparison of ABTS and DPPH methods for assessing the total antioxidant capacity of human milk, Acta Sci. Pol. Technol. Aliment, 2012. Available from: <https://pubmed.ncbi.nlm.nih.gov/22230978/>. Accessed: Nov. 18, 2018

MORO-GARCÍA, M. A. et al. Oral supplementation with Lactobacillus delbrueckii subsp. bulgaricus 8481 enhances systemic immunity in elderly subjects. Age, v.35, n.4, p.13111326, 2013. Available from: <https://www.ncbi.nlm.nih.gov/ pubmed/22645023>. Accessed: Oct. 10, 2018. doi: 10.1007/ s11357-012-9434-6.

OLIVEIRA, G.; GONZÁLEZ-MOLERO, I. An update on probiotics, prebiotics and symbiotics in clinical nutrition. Endocrinología y Nutrición (English Edition), v.63, n.9, p.482494, 2016. Available from: <https://www.sciencedirect.com/ science/article/pii/S2173509316301088>. Accessed: Jun. 21, 2018. doi: $10.1016 /$ j.endoen.2016.10.011.

OROIAN, M.; ESCRICHE, I. Antioxidants: Characterization, natural sources, extraction and analysis. Food Research International, v.74, p.10-36, 2015. Available from: <https:// www.sciencedirect.com/science/article/pii/S0963996915001817>. Accessed: Jun. 21, 2018. doi: 10.1016/j.foodres.2015.04.018.

PAIM, D. R. S. F. et al. Microencapsulation of probiotic jussara (Euterpe edulis M.) juice by spray drying. LWT - Food Science and Technology, v.74, p.21-25, 2016. Available from: <https://www. sciencedirect.com/science/article/pii/S002364381630425X>. Accessed: Nov. 12, 2018. doi: 10.1016/j.lwt.2016.07.022.

PEREIRA, E. P. R. et al. Effect of incorporation of antioxidants on the chemical, rheological, and sensory properties of probiotic petit suisse cheese. Journal of Dairy Science, v.99, n.3, p.1762-1772, 2016a. Available from: <https://www.sciencedirect.com/science/ article/pii/S0022030216000503>. Accessed: Oct. 12, 2019. doi: 10.3168/jds.2015-9701.

PEREIRA, E. P. R. et al. Oxidative stress in probiotic Petit Suisse: Is the jabuticaba skin extract a potential option?, Food Research International, v.81, p.149-156, 2016b. Available from: <https://www.sciencedirect.com/science/article/pii/ S0963996915303057>. Accessed: Oct. 12, 2019. doi: 10.1016/j. foodres.2015.12.034.

POKUSAEVA K. et al. Carbohydrate metabolism in bifidobacteria. Genes Nutr, v.6, n.3, p.285-306, 2011. Available from: <https:// www.ncbi.nlm.nih.gov/pmc/articles/PMC3145055/>. Accessed: Nov. 07, 2018. doi: 10.1007/s12263-010-0206-6.

POLETTO, G. et al. Encapsulation of Lactobacillus acidophilus and different prebiotic agents by external ionic gelation followed by freeze-drying. Cienc. Rural, v.49, n.2, 2019. Available from: <https://www.scielo.br/scielo.php?script=sci abstract\&pid $=$ S0103-84782019000200751\&lng $=$ en \&nrm $=\mathrm{iso}>$. Accessed: Feb. 23, 2020. doi: 10.1590/0103-8478cr20180729.
PISOSCHI, A. M.; POP, A. The role of antioxidants in the chemistry of oxidative stress: a Review. European Journal of Medicinal Chemistry, v.97, p.55-74, 2015. Available from: <https://www. sciencedirect.com/science/article/pii/S0223523415300039>. Accessed: Nov. 19, 2018. doi: 10.1016/j.ejmech.2015.04.040.

PAPILLO, V. A. et al. Cocoa hulls polyphenols stabilized by microencapsulation as functional ingredient for bakery applications. Food Research International, 2018. Available from: <https:// www.sciencedirect.com/science/article/pii/S0963996918307907>. Accessed: Nov. 29, 2018. doi: 10.1016/j.foodres.2018.10.004.

RADDATZ, G. C. et al. Influence of the prebiotics hi-maize, inulin and rice bran on the viability of pectin microparticles containing Lactobacillus acidophilus LA- 5 obtained by internal gelation/ emulsification. Powder Technology. v.362, n.15, p.409-415, 2020. Available from: <https://www.sciencedirect.com/science/article/ abs/pii/S0032591019310770>. Accessed: Jan. 19, 2020. doi: 10.1016/j.powtec.2019.11.114.

ROBERFROID, M. et al., Prebiotic effects: metabolic and health benefits. British Journal of Nutrition. v.104 Suppl 2: p.S1-63, 2010. Available from: <https://pubmed.ncbi.nlm. nih.gov/20920376/>. Accessed: Jun. 18, 2018. doi: 10.1017/ S0007114510003363.

RIBEIRO, A. et al. Spray-drying microencapsulation of synergistic antioxidant mushroom extracts and their use as functional food ingredients. Food Chemistry, v.188, p.612-618, 2015. Available from: $\quad<\mathrm{https} / / / \mathrm{www}$. sciencedirect.com/science/article/pii/ S0308814615007967>. Accessed: Nov. 17, 2018. doi: 10.1016/j. foodchem.2015.05.061.

REID, G. The role of Cranberry and probiotics in intestinal and urogenital tract health. Critical Reviews in Food Science and Nutrition, v.42, p.293-300, 2002. Available from: <http:// healthbenefitsofcranberryjuicehere.blogspot.com/2012/09/therole-of-cranberry-and-probiotics-in.html . Accessed: Oct. 24, 2018. doi: $10.1080 / 10408390209351918$.

SAAD, N. et al. An overview of the last advances in probiotic and prebiotic field, LWT - Food Science and Technology, v.50, p.1-16, 2013. Available from: <https://www.sciencedirect.com/ science/article/pii/S0023643812002319>. Accessed: Nov. 07, 2018. doi: 10.1016/j.1wt.2012.05.014.

SHAH, N. P. et al. Improving the stability of probiotic bacteria in model fruit juices using vitamins and antioxidants. Journal of Food Science, v.75, p.M278-M282, 2010. Available from: $<$ https://www.ncbi.nlm.nih.gov/pubmed/20629884>. Accessed: Oct. 24, 2018. doi: 10.1111/j.1750-3841.2010.01628.x.

SHINDE, T. et al. Co-extrusion encapsulation of probiotic lactobacillus acidophilus alone or together with apple skin polyphenols: an aqueous and value-added delivery system using alginate. Food and Bioprocess Technology, v.7, p.1581-1596, 2014. Available from: <https://link.springer.com/article/10.1007/ s11947-013-1129-1>. Accessed: Nov. 17, 2018. doi: 10.1007/ s11947-013-1129-1.

SILVA, P. T. et al. Microencapsulation: concepts, mechanisms, methods and some applications in food technology. Ciência Rural, v.44, n.7, p.1304-1311, 2014. Available from: <https://www.scielo. br/scielo.php?pid $=$ S0103-84782014000701304\&script $=$ sci abstract\&tlng=en $>$. Accessed: Apr. 23, 2020. doi: 10.1590/0103$8478 \mathrm{cr} 20130971$ 
SIRÓ, I. et al. Functional food, product development marketing and consumer aceptance - a review. Apettite, v.51. n.3, p.456-467, 2008. Available from: <https://www.sciencedirect.com/science/ article/pii/S0195666308004923>. Accessed: Nov. 07, 2018. doi: 10.1016/j.appet.2008.05.060.

SPINELLI, S. et al. Microencapsulation of extracted bioactive compounds from brewer's spent grain to enrich fish burgers. Food and Bioproducts Processing, v.100,p.450-456,2016.Available from: $<$ https:// www.sciencedirect.com/science/article/pii/S0960308516301055>. Accessed: Jan. 05, 2019. doi: 10.1016/j.fbp.2016.09.005.

SU, P. et al. Synergistic effect of green tea extract and probiotics on the pathogenic bacteria, Staphylococcus aureus and Streptococcus pyogenes. World Journal of Microbiology and Biotechnology, v.24, p.1837-1842, 2008. Available from: <https://link.springer. com/article/10.1007/s11274-008-9682-x>. Accessed: Sep. 09, 2018. doi: $10.1007 / \mathrm{s} 11274-008-9682-\mathrm{x}$.

TYAGI, V. V. et al. Development of phase change materials based microencapsulated technology for buildings: a review. Renewable and Sustainable Energy Reviews, v.15, n.2, p.1373-1391, 2011. Available from: <https://www.sciencedirect.com/science/ article/pii/S1364032110003461>. Accessed: Aug. 05, 2018. doi: 10.1016/j.rser.2010.10.006.

VASILJEVIC, T.; SHAH, N. P. Probiotics-from Metchnikoff to bioactives. International Dairy Journal, v.18, n.7, p.714-728, 2008. Available from: <https:/www.sciencedirect.com/science/ article/pii/S0958694608000447>. Accessed: Oct. 13, 2018. doi: 10.1016/j.idairyj.2008.03.004.

VAZIRI A.S. et al. Co-microencapsulation of Lactobacillus plantarum and DHA fatty acid in alginate-pectin-gelatin biocomposites, Carbohydrate Polymers, v.199, n.1, p.266-275, 2018. Available from: <https://www.sciencedirect.com/science/ article/pii/S0144861718307835>. Accessed: Nov. 17, 2018. doi: 10.1016/j.carbpol.2018.07.002.

WEINBRECK, F. et al. Can Encapsulation Lengthen the ShelfLife of Probiotic Bacteria in Dry Products? International Journal of Food Microbiology, v.136, n.3, p.364-67, 2010. Available from: <https://www.sciencedirect.com/science/article/abs/pii/ S0168160509005984>. Accessed: Apr. 22, 2020. doi: 10.1016/j. ijfoodmicro.2009.11.004.

WEN, P. et al. Electrospinning: A novel nano-encapsulation approach for bioactive compounds. Trends in Food Science \& Technology, v.70, p.56-68, 2017. Available from: <https://www. sciencedirect.com/science/article/pii/S0924224417302479>. Accessed: Jun. 22, 2018. doi: 10.1016/j.tifs.2017.10.009.

YASHIN, A. et al. Antioxidant and Antiradical Activity of Coffee. Antioxidants, v.2, n.4, p.230-245, 2013. Available from: $<$ https:// www.ncbi.nlm.nih.gov/pmc/articles/PMC4665516/>. Accessed: Nov. 24, 2018. doi: 10.3390/antiox2040230.

ZAEIM, D. et al. Double layer co-encapsulation of probiotics and prebiotics by electro-hydrodynamic atomization. LWT, v.110, p.102-109, 2019. Available from: <https://www.sciencedirect. com/science/article/pii/S0023643819303445>. Accessed Feb. 14, 2020. doi: 10.1016/j.lwt.2019.04.040.

ZHANG, F. et al. Co-encapsulation of $\alpha$-tocopherol and resveratrol within zein nanoparticles: Impact on antioxidant activity and stability. Journal of Food Engineering, v.247, p.9-18, 2019. Available from: <https:/www.sciencedirect.com/science/article/ abs/pii/S026087741830503X $>$. Accessed: Feb. 08, 2020. doi: 10.1016/j.jfoodeng.2018.11.021.

ZHU, F. Encapsulation and delivery of food ingredients using starch based systems. Food Chemistry, v.229, p.542-552, 2017. Available from: <https://www.sciencedirect.com/science/ article/pii/S0308814617303023 > . Accessed: Aug. 08, 2018. doi: 10.1016/j.foodchem.2017.02.101.

ZOKTI, J. et al. Microencapsulation of green tea extracts and its effects on the physico-chemical and functional properties of mango drinks. International Journal of Basic \& Applied Sciences, IJBAS-IJENS, v.16, p.16-32, 2016. Available from: $<$ http://ijens.org/Vol_16_I_02/165902-7373-IJBAS-IJENS.pdf>. Accessed: Jan. 03, 2019. 